\title{
Tysksindede arbejderes afvisning af nazismen i 1933
}

\author{
Af KitT ABRAHAMSEN
}

Denne artikel er en undersøgelse af, hvorfor tysksindede arbejdere i Sønderborg tilknyttet Socialdemokratiet i 1933 modsatte sig den nazistiske indflydelse på det tyske mindretal i Sønderjylland, og det er en analyse af, hvordan modstanden i praksis kom til udtryk. Op gennem 1930'erne oplevede det tyske mindretal en nazificeringsproces, men arbejderbevægelsen i Sonderborg kæmpede med tre ledende, tysksindede mænd i spidsen imod nazismen. Artiklen er baseret på et BA-projekt ved Syddansk Universitet fra 2010.

\section{Indledning}

Til at belyse problemstillingen er der anvendt forskningslitteratur om grænselandet og Sønderjylland samt om arbejderbevægelsens historie. Det har bidraget til at skabe et overblik over den politiske situation i perioden omkring 1933 med udgangspunkt i de socialdemokratiske holdninger, men materialet har også givet et indtryk af den spændte situation omkring kravet om grænserevision og om mindretallene på begge sider af grænsen.

Det er især tre historikeres fremstillinger, der danner baggrunden for artiklen: Frode Sørensens Revolutionen og Magten fra 2008, Troels Finks Sonderjylland siden genforeningen $i 1920$ fra 1955 og Konflikt $i$ Grænselandet skrevet af Kim Salomon i 1980. Frode Sørensens værk omhandler Socialdemokratiets udvikling i Sønderborg i perioden 1872 til 1922. Bogens tidsmæssige og geografiske indsnævring medfører en grundig analyse af arbejdernes historie i dette specifikke område, og den er baseret på et bredt kildegrundlag. Værket er anvendt som baggrundsviden i perioden op til 1933, idet Sorensen beskriver den kronologiske udvikling for arbejderne. Sonderjylland siden genforeningen $i 1920$ af Troels Fink er det ældste af de benyttede værker, og det er det, der tidsmæssigt ligger nærmest hændelserne i 1933. Finks fremstilling er ikke baseret på andre fremstillinger, men alene på primært kildemateriale samt fremstillinger udgivet $\mathrm{i}$ periodens samtid. 
Finks bog giver et godt overblik over perioden og hændelserne, som strækker sig helt frem til 1945. Fink var en meget dansksindet historiker og forfatter ${ }^{1}$, og det må antages, at han gennem en dansk kildeudvælgelsesproces kan have lagt vægt på dansk-støttende kilder, der igen kan have påvirket hans vurdering. Kim Salomons værk Konflikt $i$ Grænselandet fra 1980 er anvendt til at give overblik over grænselandskonflikten. Afhandlingen forholder sig kritisk til andre fremstillinger, og indholdet hviler på et stort kildegrundlag fra arkiver $\mathrm{i}$ både Danmark og Tyskland. Bogens oplysninger er blevet verificeret gennem det valgte primære kildemateriale.

Kildematerialet består af offentlige aviser og private kilder i form af protokolmateriale. Det primære kildemateriale er brugt til at få indsigt $\mathbf{i}$ holdningen omkring den nazistiske indflydelse. De to kildegrupper er anvendt med ligelig vægtning. Avismaterialet er fra Sønderborg Social-Demokrat, Dybbol Posten, Jydske Tidende og Hejmdal. De forskellige aviser havde forskellige politiske udgangspunkter, og de blev især brugt til at påvirke opinionen. De private kilder er protokolmateriale fra Lokalhistorisk Arkiv for Arbejderbevægelsen i Sønderborg Kommune, og selvom mange hændelser beskrives i aviserne, er fremstillingen - grundet forskellige målgrupper - i protokollerne ofte mere detaljeret og ud fra et andet udgangspunkt. I protokollerne er der ikke blevet lagt vægt på særlige formuleringer, der skulle få personer eller hændelser til at fremstå anderledes over for offentligheden. De anvendte protokoller er fra 1933 til 1935, og de indeholder beslutningsreferater og samtaler ud fra et socialdemokratisk synspunkt samt interne politiske strategier og overvejelser.

\section{Den tyske modstand}

I 1930'erne gennemgik det tyske mindretal i Danmark en ensretning og nazificeringsproces, der var forårsaget af blandt andet den økonomiske afhængighed af Tyskland og den fremherskende konservative nationalisme. De, der inden for mindretallets kredse søgte at tage afstand til nazismens indflydelse, dannede efter Anden Verdenskrig det nye demokratiserede tyske mindretal. Denne mindre gruppe - kaldet Haderslevkredsen - fik dog først offentligt mæle efter krigen. ${ }^{2}$

Der findes flere værker, der beretter om et voldsomt pres på mindretalsmedlemmerne, som i situationer medførte handlinger og holdninger af nazistisk karakter, men der foreligger ingen direkte kil- 
der til disse formodninger. Dette, kombineret med manglende kildemateriale, gør det vanskeligt at beskrive dem, der i 1930'erne inden for mindretallets egne kredse tog afstand fra nazificeringsprocessen.

Der fandtes dog en anden gruppe af tyskere i Danmark, der udtrykte stærk modstand mod nazismen i Tyskland og mod den spirende nazistiske udvikling i Danmark. Arbejderbevægelsen slog ind på en klar antinazistisk linje i 1933, og hensigten var at eliminere de nationale modsætninger i Sønderjylland. ${ }^{3}$

Arbejderne i Sønderjylland bestod på dette tidspunkt af en blandet gruppe mennesker. Der var både tyske immigranter sydfra, som var blevet integreret, og dansksindede arbejdere. Det var i særdeleshed i Sønderborg, at disse tysksindede arbejdere i slutningen af 1800-tallet var grundlæggere af socialdemokratiske foreninger. Skønt en tilgang af dansksindede medlemmer vedblev Socialdemokratiet med at have tysksindede medlemmer i ledelsen. ${ }^{4}$ Da Hitler i 1933 overtog magten i Tyskland, tog Socialdemokratiet i Sønderjylland officielt afstand fra den nationalsocialistiske ideologi. Dette skete ved et møde i Tinglev i april 1933, hvor en resolution mod nazismen blev vedtaget. ${ }^{5}$

For at opnå en forståelse af, hvorfor de tysksindede arbejdere tilknyttet Socialdemokratiet i Sønderborg i 1933 modsatte sig den nazistiske indflydelse på det tyske mindretal i Sønderjylland, og hvordan denne modstand i praksis kom til udtryk, er det væsentligt at foretage en afgrænsning af tid og sted.

Der var to grupper af tysksindede i Nordslesvig: det tyske mindretal, der bestod af tysksindede, som havde boet i Nordslesvig før Genforeningen, og tysksindede arbejdere, der fra slutningen af 1800-tallet kom til Nordslesvig fra andre dele af Tyskland.

I Sønderjylland var Socialdemokratiet opdelt i syv kredse indtil 1938, hvoraf denne artikel primært beskæftiger sig med Sønderborgkredsens medlemmer. Arbejderbevægelsen er den anvendte betegnelse for arbejderklassens forskellige organisationer. Det er en samlet fællesbetegnelse for de politiske dele, fagforeningerne og kooperative bevægelser. Arbejderbevægelsen var yderligere delt i to grene, nemlig den kommunistiske og den socialdemokratiske. ${ }^{6}$ Artiklen er afgrænset til at have fokus på den socialdemokratiske del af arbejderbevægelsen.

Socialdemokratiet var arbejderbevægelsens politiske parti. Det blev grundlagt i Sønderborg i 1904 af tyske arbejdere, der var kommet sydfra. Disse arbejdere kom typisk fra Slesvig-Holsten, Mecklenburg, 
Pommern, Thüringen, Brandenburg, Schlesien og Sachsen. ${ }^{7}$ Mange blev gift med en dansk pige, hvilket var med til at sikre en ofte vellykket integration. Gruppen af tysksindede i Danmark udgjorde et tysk mindretal efter 1920, og egentlig tilhørte de tysksindede arbejdere denne kategori. Efter grundlæggelsen af mindretallets parti, det borgerlige Schleswigscher Wählerverein (SW), blev der et skel mellem det tyske mindretal, som sluttede op bag SW, og de tysksindede arbejdere tilhørende arbejderbevægelsen. Mange af arbejderne var desuden født i Tyskland uden for Nordslesvig, mens det tysksindede mindretal var en del af den oprindelige befolkning i Nordslesvig. ${ }^{8}$

Efter grænsedragningen i 1920 blev der efterladt et nationalt mindretal på begge sider af grænsen. Den tysksindede del af befolkningen i Nordslesvig blev af det tyske udenrigsministerium anslået til at udgøre 25-30.000 personer. Det tyske mindretal, der udgjorde en sjettedel af befolkningen i Nordslesvig, delte ikke politiske holdninger med de tysksindede arbejdere, der var splittede. De havde et tilhørsforhold til den tyske mentalitet og kultur, men støttede på samme tid op bag det danske Socialdemokratis politiske værdier. I Sønderborgområdet var de tysksindede arbejdere grundlæggere af de første socialdemokratiske organisationer, men ved Genforeningen i 1920 blev de tyske og danske arbejderafdelinger samlet under ét Socialdemokrati. ${ }^{9}$ Splittelsen blev særligt tydelig, da den borgerlige fløj i det tyske mindretal i Danmark grundlagde SW med den tysknationale pastor Johannes Schmidt i spidsen. Det var en organisation, hvor de tysksindede arbejdere ikke var repræsenteret. ${ }^{10}$

Det indbyrdes forhold blandt de tysksindede i perioden efter 1920 var klart: Der var et splittet tysk mindretal, hvor arbejderne ikke ønskede at støtte op om de borgerliges politik, og hvor de borgerlige på samme vis ikke ønskede arbejdernes deltagelse. Splittelsen i mindretallet og de borgerliges udvikling er nogle af de væsentlige faktorer $i$ spørgsmålet om, hvorfor og hvordan de tysksindede arbejdere valgte at tage afstand til nazificeringen af det tyske mindretal.

\section{Det tyske mindretal blev støttet fra Tyskland}

Mindretallets politik bar et klart nationalt præg, og formanden for SW, pastor Schmidt, havde i perioden efter 1918 kæmpet for en bevarelse af landsdelen under det tyske herredømme. Vælgerforeningen blev mindretallets politiske talerør og ansigt udadtil. ${ }^{11}$ Partiprogram- 
mets kerne var en grænserevision samt at manifestere styrken indadtil. I et valgoplæg i 1920 udtrykte Schmidt, at "Jeder Stimme sei ein Gelübde der Treu zum deutschen Volk «. ${ }^{12}$ En kommentar, der tydeligt udtrykte vigtigheden af det nationale tilhørsforhold.

Allerede i denne tidlige periode fik mindretallet økonomisk og politisk støtte fra Tyskland. Der var flere foreninger og institutioner i Tyskland, der interesserede sig for tyskheden i Nordslesvig, og de skaffede blandt andet penge til oprettelsen af private skoler i området.

Ved det første folketingsvalg efter Genforeningen i 1920 oplevede SW en tilbagegang, sammenlignet med antallet af stemmer ved folkeafstemningen 10. februar 1920 . Ved afstemningen stemte ca. $25 \%$ til fordel for Tyskland, og ved folketingsvalget opnåede vælgerforeningen blot $14,4 \%$ af stemmerne. De to vidt forskellige valg burde ikke sammenlignes, da de fandt sted under forskellige omstændigheder og med forskellige formål, men ikke desto mindre mente mindretallet selv, at der var et sammenligningsgrundlag. Pastor Schmidt forklarede blandt andet mindretallets faldende støtte med en lav tysksindet stemmeprocent, og han mente, at de tysksindede arbejdere havde stemt på det danske Socialdemokrati. Splittelsen var klar og tydelig, og den vedblev at være sådan. I et valgoplæg til folketingsvalget $i$ 1924 forklarede vælgerforeningen over for de tysksindede arbejdere, at de skulle stemme tysk, da de ikke kunne vente sig noget godt af Socialdemokratiet. Mindretallets propaganda blev ført med nationalt fortegn i stedet for et økonomisk og socialt, da de ikke på disse områder kunne appellere til de tysksindede arbejdere. ${ }^{13}$

I 1922 kom der en opfordring fra Berlin om, at mindretallets ledelse kunne lave en tysknationalistisk paraplyorganisation, der rummede alle tysksindede $\mathrm{i}$ grænselandet, også selv om de havde afvigende politiske overbevisninger. Vælgerforeningen afslog hurtigt opfordringen, og pastor Schmidt udtalte offentligt, at han ikke var socialdemokrat. Det må antages, at den økonomiske støtte fra Tyskland også har været medvirkende til at opretholde det tyske nationale tilhørsforhold, som Kim Salomon har beskrevet det i Konflikt $i$ Grænselandet om de sociale og nationale modsætninger i Sonderjylland. ${ }^{14}$

\section{Arbejderne kæmpede mod nationale modsætninger}

De tysksindede arbejdere var kulturelt knyttet til tyskheden, og mange havde børn, der gik i tyske skoler og oftest med tysk som 


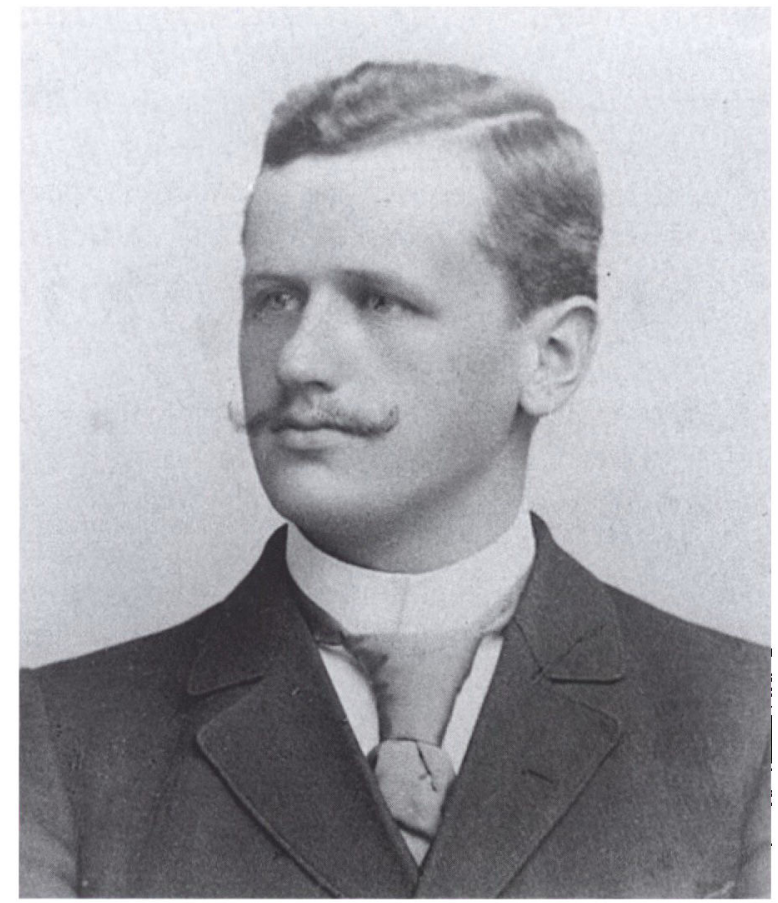

På billedet ses pastor Johannes Schmidt, der var leder af Schleswigscher Wählerverein fra 1920. Partiet forte en nationalkonservativ politik, som bod mange tyske arbejdere $i$ Nordslesvig imod. Derfor valgte mange tyske arbejdere at bakke op bag det fxiles dansk-tyske Socialdemokrati $i$ stedet. Foto: Museum Sonderjylland - ISL-Lokalhistorie.

sprog i hjemmet. Der var dog også mange, som var blevet dansk gift, og hvor børnene gik i de danske skoler. Politisk støttede de dog op om Socialdemokratiet, hvor hensigten var at eliminere nationale modsætninger og opbygge et internationalt socialistisk samfund. ${ }^{15}$ Valgpjecer blev trykt på både tysk og dansk, og de nationale modsætninger blev håndteret forsigtigt.

I tiden inden 1920 havde der været et tysk Socialdemokrati i Nordslesvig, og det var naturligt, at dette blev indlemmet under det danske, da landsdelen blev genforenet med Danmark i 1920. Mange af Socialdemokratiets medlemmer var derfor tysksindede. ${ }^{16}$ Arbejderne valgte ikke at støtte op om mindretallets vælgerforening, da de fandt, at samfundspolitiske problemer var vigtigere end det nationale tilhørsforhold. ${ }^{17}$ I 1933 kulminerede konflikten imellem de tysksindede, 
da Socialdemokratiet tog afstand fra nazismens indflydelse i Danmark, hvilket både gjaldt inden for de danske og inden for de tyske kredse, herunder altså også i forhold til det tyske mindretal. Splittelsen betød også, at det nærmest var umuligt for mindretallet at modstå en nazificering, ønskværdigt eller ej, da det økonomisk og politisk var afhængigt og infiltreret af Tyskland. På dette punkt stod de tysksindede arbejdere frit, og det var muligt at tage afstand fra nazificeringen. Hvis Berlins opfordring i 1922 om én samlet tysk organisation i Nordslesvig med forskellige politiske holdninger, men med nationalismen som fællesnævner, var blevet gennemført, ville det måske ikke have været muligt for de tysksindede arbejdere at undgå nazificeringen.

I Sønderborgs arbejderbevægelse var der nogle helt centrale, tysksindede mænd, der fortsat i 1933 var med i ledelsen. En af dem var byrådsmedlem og tidligere 2. viceborgmester, Carl Friedrich Oscar Preuss, der var elektriker. Han blev født i Rathenow ved Berlin i 1883 og kom til Als i 1903. Han flyttede til Sønderborg i 1920, og det var også her, han døde 32 år senere. I juni 1920 blev han udvist fra Danmark af Den Internationale Kommission, men allerede i november fik han af justitsministeren tilladelse til at vende tilbage. Op gennem 1920'erne havde Preuss forskellige roller inden for den tyske arbejderbevægelse. Han var blandt andet formand for Deutsche Metallarbeiter Verband, næstformand i Sønderborgs Socialdemokrati og medstifter af Arbejdersangforeningen, mens Preuss' kone fra 1932 var formand for Kvindeligt Arbejderforbund. ${ }^{18}$ Oscar Preuss er ligeledes nævnt mange steder $i$ den Socialdemokratiske forenings protokolmateriale i perioden 1933 til 1935, fordi han var bestyrelsesmedlem, og han har derfor deltaget ved mange af de socialdemokratiske partimøder. ${ }^{19}$ Han var en vigtig og en meget politisk og fagligt aktiv mand i Sønderborgområdet og inden for arbejderbevægelsen. Han støttede fuldt op bag den socialistiske og anti-nazistiske linje, der blev lagt, til trods for sin tyske herkomst og identitet. Oscar Preuss blev som mange andre tyske immigranter - gift med en lokal dansk pige. Dette var medvirkende til en vellykket integration i det danske samfund.

Skomager Friedrich Wilhelm Lange var en anden central, tysksindet mand i Socialdemokratiet i Sønderborg. Lange blev født i Schlesien i 1874. Han flyttede til Nordslesvig, hvor han i 1901 blev gift med danske Anna Margarethe Knudsen i Sønderborg. Frem til 1934 havde 
Lange en faglig og politisk karriere. I perioden fra 1904 til 1934 var han en del af den socialdemokratiske top som næstformand, bestyrelsesformand eller kasserer. ${ }^{20}$ På trods af at han aldrig blev dus med det danske sprog, lykkedes det ham alligevel at integrere sig såvel socialt som politisk i Sonderborg. ${ }^{21}$ Langes politiske virke og tilslutningen til bekæmpelsen af nazismen kommer ofte til udtryk i arbejderbevægelsens protokolmateriale. Ifølge flere mødereferater var han aktivt deltagende, og han udtrykte blandt andet vigtigheden af at bekæmpe den danske nazisme. ${ }^{22}$ Ligeledes er Lange et symbol på vedligeholdelsen og interessen for den tyske kultur og historie - også inden for de socialdemokratiske kredse. Et mødereferat fra 1935 beretter blandt andet om, at Lange skulle holde tale ved den planlagte "tyske aften «, og talen skulle omhandle Tyskland i perioden fra 1890 til 1912.23

Når man skal belyse de tysksindede arbejderes afstand til nazificeringen, er det væsentligt også at nævne Heinrich Wollrath Christian Eckhardt. Han blev født i Schwichfeldt i Tyskland i 1884 og døde i Sønderborg i 1943. I 1908 kom Eckhardt til Sønderborg, og han var fagligt og politisk aktiv frem til sin død. Indtil Genforeningen i 1920 var han medstifter og formand for flere tyske arbejderforbund. Efter Genforeningen blev han formand for blandt andet Dansk Murerforbund og Socialdemokratisk Forening. Derudover var han også medlem af Sønderborg byråd indtil sin død. ${ }^{24}$ Frem til 1933 var Eckhardt formand for den socialdemokratiske partiforening i Sønderborg, og han er derfor at finde i alt protokolmaterialet i perioden 1933 til 1935. I mødereferaterne beskriver han ofte vigtigheden af at have forståelse for de tysksindede medlemmer af Socialdemokratiet og betydningen af ikke at støde disse medlemmer fra sig. ${ }^{25}$ Eckhardt var den mest fremtrædende socialdemokrat af tysk herkomst, og han udtrykte ofte sin mening om nazismen offentligt. Han skrev blandt andet flere læserbreve til Sønderborg Social-Demokrat, der alle var af opsigtsvækkende karakter. I juli 1933 skrev han således om ødelæggelsen af den tyske ærlighed forårsaget af de nazistiske magthavere. Han kritiserede blandt andet tyskernes mangel på ansvarsfølelse. ${ }^{26}$ Andre eksempler på Eckhardts direkte måde at udtrykke sin utilfredshed på ses i september 1933, hvor han skrev om den negative udvikling i Tyskland, som han så. ${ }^{27} \mathrm{I}$ en anden artikel skrev han om det tyske mindretals leder, pastor Schmidts, »uærlige veje«, og her angreb og kritiserede han ikke kun pastoren, men også SW. ${ }^{28}$ 
De tre nævnte socialdemokratiske mænd af tysk herkomst har alle - på hver sin vis - bidraget aktivt og politisk til dannelsen og definitionen af Socialdemokratiet i Sønderborg i tiden fra før Genforeningen til efter Hitlers magtovertagelse og den senere besættelse af Danmark. De er alle eksempler på, hvor stor betydning den politiske ideologi og overbevisning havde, men de vidner også om, at de samtidig ønskede at værne om deres tyske identitet og tilhørsforholdet til tysk kultur. Dette var dog ikke ensbetydende med en støtte til det nazistiske regime i Tyskland.

Efter Eckhardts død rejste arbejderbevægelsen og hans venner en mindesten for ham for at hylde og bevare mindet om en tysk indvandrer, der kæmpede for et Danmark uden nazistisk indflydelse. ${ }^{29}$

For at opnå en forståelse for, hvorfor og hvordan de tysksindede arbejdere i Sønderborg efter Hitlers magtovertagelse i foråret 1933 modsatte sig den nazistiske indflydelse på det tyske mindretal, er det vigtigt med en forståelse af, hvordan Sønderborgs Socialdemokrati var skruet sammen. De tysksindede arbejderes splittelse mellem et tysknationalt tilhørsforhold på den ene side og en betydelig socialdemokratisk overbevisning på den anden kom til udtryk gennem den tyske socialdemokratiske forening SPD-Sonderburg. I $1918 \mathrm{kom}$ et stort dansk gennembrud, og den danske Sønderjysk Arbejderforening nåede hurtigt op på samme antal medlemmer, som det tyske broderparti havde. ${ }^{30}$ Året efter etablerede arbejderpartierne et stærkere og stærkere samarbejde.

Frode Sørensen har i Revolutionen og Magten om arbejderhistorien i Sønderborg frem til 1922 vurderet, at størstedelen af de tysksindede arbejdere i Sønderborg formodentligt stemte tysk ved folkeafstemningen i 1920. De støttede op om den nye republik og afskaffelsen af kejseren, og en mulig indlemmelse i Danmark ville betyde, at man blev en del af det, mange anså som et forældet monarki. En mulig indlemmelse var altså ikke en ønskværdig situation for de tysksindede arbejdere, men den politiske dagsorden rangerede alligevel højere, og vigtigheden af det socialdemokratiske sammenhold var af større betydning end det nationale sammenhold. Dét, der samlede arbejderbevægelserne under ét dansk Socialdemokrati, var en udtalelse fra de tysksindede arbejdere, der meget tydeligt illustrerer de tysksindedes tankegang: "I dag er vi tyske arbejdere, i morgen er vi danske arbejdere, men først og fremmest er vi socialdemokrater. « ${ }^{31}$

Situationen i Sønderborg var genkendelig mange andre steder i 


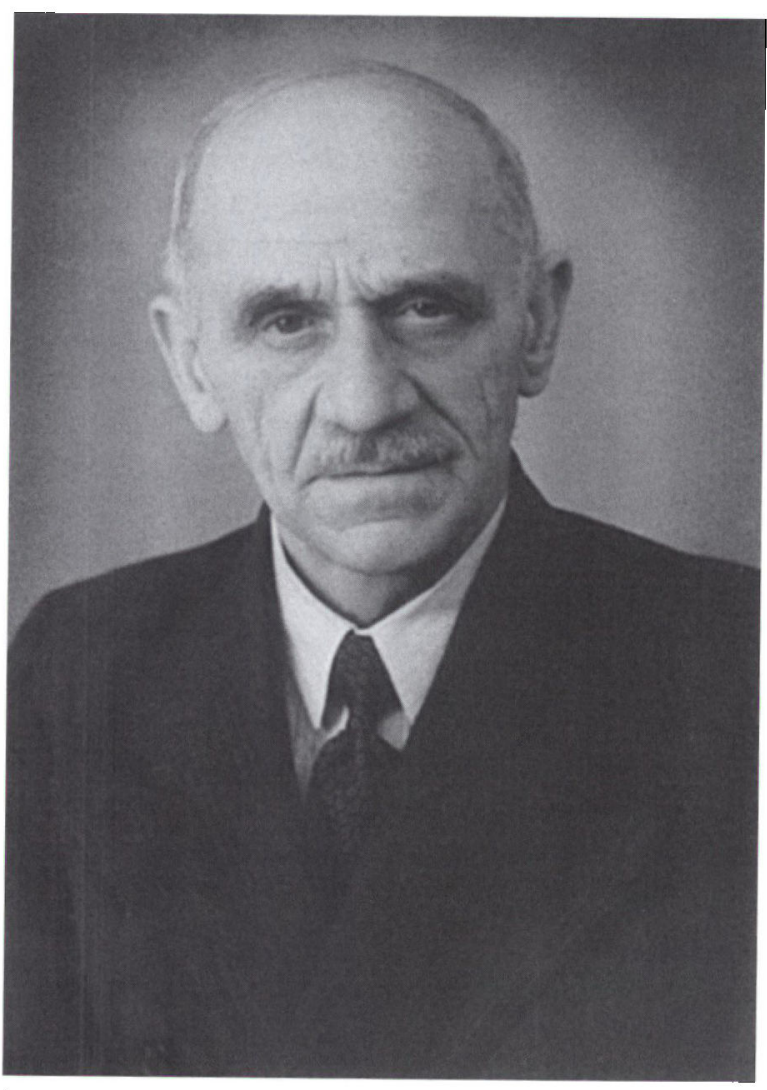

Carl Friedrich Oscar Preuss var elektriker og flyttede til Als i 1903 og til Sonderborg $i$ 1920. Selv om han var fodt $i$ Tyskland, var han med $i$ ledelsen af det fxlles dansktyske Socialdemokrati $i$ 1933, og han var meget aktiv modstander af nazismen. Foto: Lokalhistorisk Arkiv for Arbejderbevagelsen i Sønderborg Kommune.

Nordslesvig. Fra tysk side frygtede man, at nederlaget efter Første Verdenskrig ville medføre, at Nordslesvig blev genforenet med Danmark. Frygten dannede grundlag for lokale tyske udvalg, der skulle tage til genmæle mod den danske propaganda. Udvalgene blev dannet $\mathrm{i}$ blandt andet Tønder, Aabenraa og Sønderborg. Udvalget bestod af repræsentanter for det tyske mindretal med de tyske landråder og redaktører i spidsen, men også repræsentanter for de tyske socialdemokrater deltog. Efter revolutionen i 1918 trak socialdemokraterne sig dog ud af de tyske udvalg. ${ }^{32}$ Billedet var klart; man nærede ikke 
ønske om indlemmelse i Danmark, og den senere afstemnings udfald var ikke noget, de tysksindede arbejdere i Sønderborg eller i Nordslesvig ønskede.

Socialdemokraterne behandlede emnet om en grænserevision på forskellige måder. Der var en fløj, som helt afviste en revision af den dansk-tyske grænse, medmindre der var to tredjedele dansk flertal for det. I andre socialdemokratiske partiforeninger gik man ind for selvbestemmelsesretten, men var imod en eventuel afståelse. Partiforeningerne i Haderslev og Sønderborg gik i foråret 1919 i en mere danskorienteret retning. Yderligere udsendte den slesvig-holstenske socialdemokratiske forening et opråb om, at det på socialistkonferencen i Bern var vedtaget, at områder med nationalt flertal under en afstemning skulle tilfalde det pågældende land. ${ }^{33}$

\section{Til kamp mod nazismen}

Op gennem 1930'erne blev den nazistiske udvikling fulgt nøje gennem aviserne. Da Hitler overtog magten i januar 1933, blev det iagttaget fra mange forskellige tilgangsvinkler. Fra borgerlig dansk side så man på det med bekymring, men det udgjorde ikke hoveddelen af spaltepladsen i aviserne. Det var Danmarks finansielle situation, der prydede forsiderne.

De borgerlige aviser i lokalområdet, Dybbøl-Posten og Hejmdal, berettede om Hitlers tiltrædelse og nazismens udvikling i Tyskland. I løbet af januar og februar i 1933 var der løbende artikler om nazismens fremmarch. De fleste var af berettende og lettere bekymret karakter. Endvidere var disse to aviser i samme periode meget optaget af de internationale forhold og den økonomiske krises konsekvenser for særligt arbejdsgiverne, hvilket optog en del spalteplads. Jydske Tidende berettede i samme periode om Hitlers genialitet og dygtighed. Deres opfattelse af nazismens fremmarch og udvikling i Tyskland var ikke så negativ som hos de øvrige borgerlige aviser $\mathrm{i}$ området. Det gav anledning til mange debatter og megen kritik, hvor Dybbøl-Posten og Hejmdal stod sammen med Sønderborg Social-Demokrat i kritikken af Jydske Tidendes nazi-venlige linje.

Socialdemokraterne i Sønderborg forholdt sig den 31. januar 1933 afventende over for den nye Hitler-regering. Der var en dyb skepsis, men partiet ønskede først at se den nye regerings udspil. Allerede få dage efter Hitlers tiltrædelse bragte den socialdemokratiske avis ar- 
tikler om nazismens sande indhold af ondskab og vold under overskrifter som »Tyskland i Blodets tegn «. ${ }^{34}$

Situationen i Tyskland med mange protester, demonstrationer og blodige oprør forfærdede mange. De tysksindede arbejdere i Danmark så, hvad venner og familie blev udsat for i Tyskland. I februar måned blev socialdemokraternes blade forbudt $\mathrm{i}$ Tyskland, og flere især kommunister - blev forfulgt og dræbt. »Flere dræbte, nazi frikendes", skrev Sonderborg Social-Demokrat den 6. februar 1933 om de nazistiske gerningsmænds frikendelse af overgrebene, hvilket skabte stor ængstelse og frygt. ${ }^{35}$ I Danmark gik mange af de tysksindede arbejderes børn i de tyske skoler, og da nazificeringen blev mere entydig, vakte dette ligeledes stor utilfredshed $\mathrm{i}$ arbejderkredse. ${ }^{36}$ Situationen blev blandt andet beskrevet i Dybbøl Posten i starten af april under overskrifterne "Det tysk-nationalsocialistiske Fremstød i Nordslesvig " og »De tyske Grænseflyttere

Det var noget særligt for Sønderborgs arbejdere, at de trådte frem på et meget tidligt tidspunkt og offentligt erklærede en afstand til nazismen. Årsagen hertil ses bedst gennem et uddrag af en artikel i Sønderborg Social-Demokrat fra marts 1933: "Hvis man virkelig tror, at tyske arbejdere istemmer jublen over nazismens sejr, så tror man fejl. Blandt forstandige tyske arbejdere i Sønderjylland råder både forfærdelse og frådende harme over de umenneskeligheder, nazisterne må tage ansvaret for, mange tyske arbejdere frygter $i$ dag for venners og slægtninges skæbne syd for grænsen, om de skal blive ofre for nazisternes morderkugler eller djævelske mishandlinger. ${ }^{37}$

2. påskedag, den 17. april 1933, havde arbejderbevægelsen i Sønderjylland fået nok og gik i aktion under ordene "Kampfront mod Nazi«. Mødet blev holdt på Tinglevhus, og omkring 300 repræsentanter for de syv socialdemokratiske kredsbestyrelser, socialdemokratiske partiforeninger i den sønderjyske storkreds samt repræsentanter for fællesorganisationer i Det Sønderjyske Fællesudvalg var samlet. ${ }^{38}$ Målet med Tinglevmødet var at tage kampen op mod nazismen og at værne sig imod nazi-kulturen i Danmark. Blandt andet blev det slået fast, at det sønderjyske Socialdemokrati ikke ville tolerere tjenestemænds indblanding i nazismen, og at der burde ske en undersøgelse af de tyske privatskolers nazi-agitation. Til slut blev en resolution vedtaget og motiveret af redaktør Frede Nielsen. Talen indeholdt en klar linje om, hvorledes arbejderne burde agere over for nazismen ved at bryde alle forbindelser til medlemmer af nazistiske organisa- 


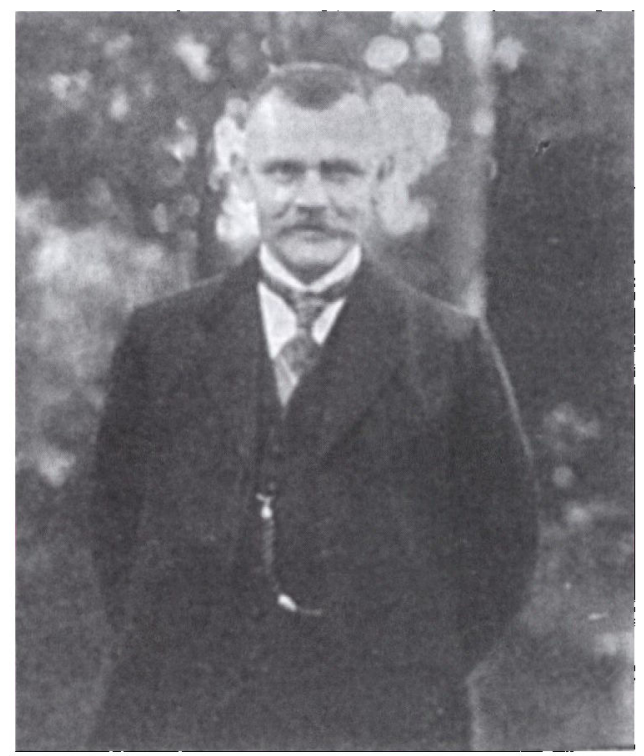

Skomager Friedrich Wilhelm Lange var fodt $i$ Schlesien, men flyttede til Nordslesvig og blev dansk gift. Han var meget aktiv $i$ Socialdemokratiet $i$ Senderborg frem til 1934 som næstformand, bestyrelsesformand og kasserer. Han tog stærkt afstand fra nazismen. Foto: Lokalhistorisk Arkiv for Arbejderbevægelsen i Sonderborg Kommune.

tioner og til det nazistisk infiltrerede tyske mindretal i Danmark. Talen opfordrede også det tyske mindretal til at støtte arbejderne $\mathbf{i}$ kampen mod nazismens indflydelse i Danmark. Gentagne gange benæuntes nazismens udvikling som en hån mod friheden og socialismen, hvor sammenhold var midlet til bekæmpelse.

I resolutionen blev tanken om en grænseflytning fra tysk side beskrevet som en hån mod friheden og folkeretten og anset som en tilbagevenden til voldspolitikken. Grænsen blev fremhævet som det nordiske folks grænse, der var fastlagt i henhold til befolkningens frie afgørelse ved grænseafstemningen i 1920. Ydermere blev det slået fast, at den socialdemokratiske partiforening ønskede at bekæmpe nazismens med hele organisationens styrke. Resolutionen understregede, at en selvfølgelig konsekvens af nazismens politik over for socialismen betød, at alle forbindelser mellem medlemmer af nazistiske organisationer og arbejdere blev afbrudt. Tinglev-resolutionen af 17. april 1933 blev afsluttet således:

»Vi tilråber den del af de tyske arbejdere, som hidtil politisk har 
ydet de tysk-borgerlige deres støtte: Øjeblikket er inde til, at I bryder med denne hidtil fulgte linje og sammen med jeres dansk-tyske kammerater vender jer mod denne truende fare. Vi retter en indtrængende appel til alle sønderjyske arbejdere om at stå ubrydeligt sammen i denne kamp, der nu er indledt. Vi lader os ikke skræmme af trusler og lader os ikke løbe over ende. Under mottoet: Enighed, disciplin og aktivitet går vi til arbejdet og kampen. Leve socialismen!«

Forsamlingen nedsatte yderligere en aktionskomité bestående af syv kredsformænd og med redaktør Swanholm som formand. Denne komité skulle tilrettelægge kampagnen, der skulle modarbejde enhver form for nazi-agitation.

I Sønderborg blev der den 20. april 1933 afholdt ekstraordinær generalforsamling i partiforeningen, hvorefter alle socialdemokratisk indstillede arbejdere efter en diskussion endte med at støtte op om resolutionen fra Tinglevmødet, der var vedtaget tre dage forinden, samt med det tilføjede løfte om, "... at vi af al magt vil være med i det arbejde, som nu er tilrettelagt i denne kamp«. Yderligere krævede man udvisning af alle udlændinge, der ville udbrede den nazistiske ideologi i Danmark. ${ }^{39}$

\section{Arbejderne tager afstand}

Vedtagelsen af resolutionen af 17. april 1933 samt nedsættelsen af aktionskomitéen blev starten på det sønderjyske folks eget værn af grænsen. I de efterfølgende måneder manifesterede folket sig i store møder og resolutioner med krav til kongen og regeringen. Arbejderbevægelsens afstandstagen kom således til udtryk gennem idrætsstævner, komitéer og grupper. ${ }^{40}$

Den 12. maj 1933 samledes 15.000 unge til et ungdoms- og idrætsstævne i Tønder, der for omverdenen skulle udstråle en stærk danskhed i Nordslesvig. Ud over de sportslige begivenheder blev der holdt taler med politiske budskaber, der blev givet løfter for fremtiden, og der blev opfordret til mod og styrke for arbejdet for Danmarks sag. Ungdomsstævnet i Tønder var det største ungdomsstævne nogensinde $i$ området, og ved siden af de sportslige indslag var det vigtigste at symbolisere, at »Vi står som Danmarks nationale grænseværn mod syd", som det blev udtrykt i avisen Hejmdal i maj 1933. ${ }^{41}$

De store forsamlinger af unge sportsinteresserede med en politisk dagsorden fortsatte. I juni 1933 var der op imod 50.000 mennesker 
samlet ved et stort anti-nazistisk stævne i Dybbøl for at tilkendegive danskheden. Stævnet var arrangeret af den borgerlige fløj. ${ }^{42}$ Der var tilsvarende socialdemokratiske stævner i Sønderhav, Gråsten og Augustenborg hen over sommeren. ${ }^{43}$ Sommerstævnerne var et led i aktionskomitéens kampagne mod nazismen. Det fremgår af Socialdemokratiets mødeprotokol, at man håbede at udnytte den stemning, stævnerne havde udløst, til i efteråret at give partipressen den største fremgang. ${ }^{4}$

Fra arbejderpartiets kerne var der også stor tilslutning til den antinazistiske politik, der blev ført med stor påpasselighed over for de tysksindede medlemmer af partiet. Socialdemokratiet var opmærksom på ikke at støde de tysksindede medlemmer fra sig. Der blev ligeledes afholdt danske såvel som skandinaviske aftener og senere også tyske aftener for at glæde alle medlemmer. Dette var aktuelt i 1933, som det var i årene efter. ${ }^{45}$

Ved partimødet i Sønderborg den 31. juli 1933 blev der opfordret til at tegne abonnement på de landflygtige tyske socialdemokraters blad Neues Vorwärts. En sådan opfordring viser klart partiets ståsted: først socialdemokrat, dernæst national. Endvidere blev det endnu engang slået fast, hvorledes man ønskede at bekæmpe nazismen: »Vi må agitere, men vi må også kræve, at der skrides ind med hård hånd fra regeringens side over for nazisterne.« Ved samme møde blev det også erklæret for centralt at bekæmpe den danske såvel som den tyske nazisme. ${ }^{46}$

Der hersker ingen tvivl om, at de tysksindede arbejdere var meget påvirkede af den begyndende nazificering af det tyske mindretal i første halvår af 1933. Det skyldtes blandt andet, at mange var brugere af de tyske skoler, men mindst lige så vigtigt var det, at de kunne se, hvilke konsekvenser nazismen fik for venner og familie i Tyskland. En anden væsentlig årsag til arbejdernes afstandstagen til nazificeringen af det tyske mindretal var det splittede tilhørsforhold. Fælles for arbejderne var, at de først og fremmest havde et fælles politisk ståsted. Dernæst var nationaliteten gældende. I det borgerlige tyske mindretals lejr var situationen modsat. Her var man tysk af sind og sjæl, og dette skabte en meget nationalistisk politisk linje, som arbejderne ikke kunne forenes med.

Tinglev-resolutionen blev vedtaget $\mathrm{i}$ april 1933, blot tre måneder efter Hitlers magtovertagelse. Afstanden til nazificeringen kom klart til udtryk gennem den nedsatte aktionskomité. Denne gruppes opga- 


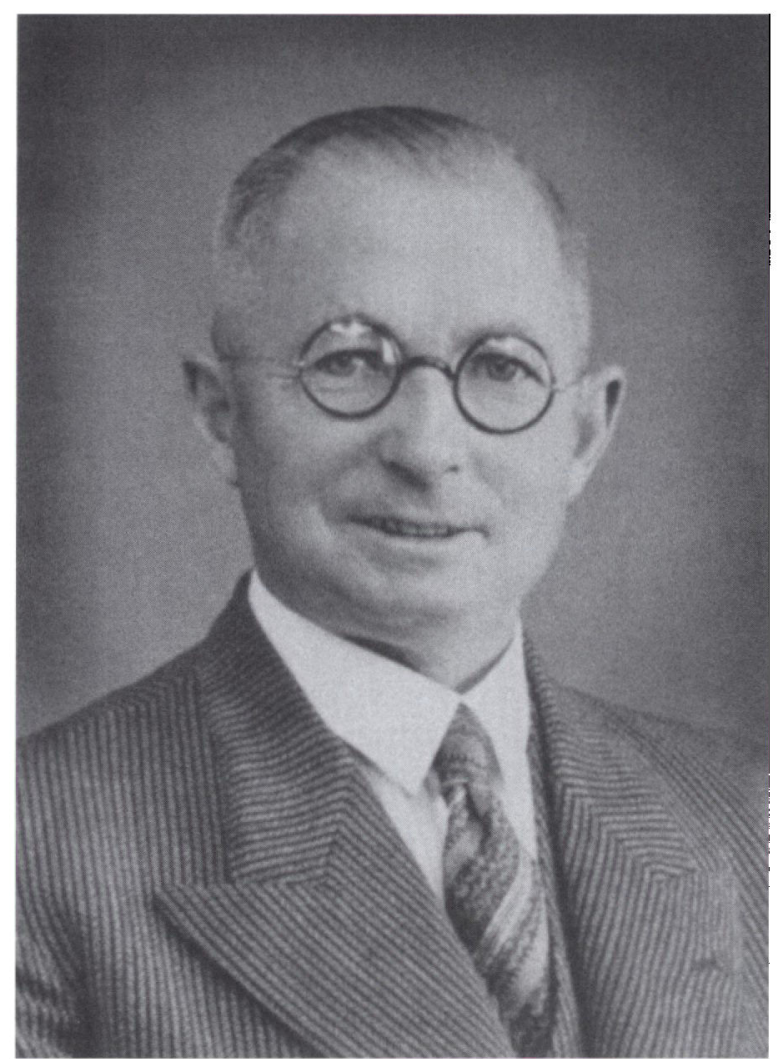

Heinrich Wollrath Christian Eckhardt var fodt $i$ Schwichfeldt $i$ Tyskland, men kom til Sønderborg $i$ 1908. Frem til sin død $i 1943$ var han meget aktiv inden for blandt andet Dansk Murerforbund og Socialdemokratisk Forening. Han skrev blandt andet artikler $i$ Social-Demokraten $i$ Sonderborg, hoor han tog stærkt afstand fra nazismen og fra Johannes Schmidt og Schleswigscher Wählerverein. Foto: Lokalhistorisk Arkiv for Arbejderbevæelsen i Sonderborg Kommune.

ve var at bekæmpe både dansk og tysk nazisme, og som en del af kampagnen var styrkelsen af danskheden. Der blev blandt andet afholdt de tidligere nævnte store anti-nazistiske sportsstævner. Herigennem fik de dansk- såvel som de tysksindede en fællesfølelse. Det sønderjyske folk mobiliserede selv et grænseværn med de midler, de havde.

Skoleområdet var et andet vigtigt sted, hvor aktionskomitéen og partipressen kunne påvirke opinionen. Efter oget pres og opmærksomhed på de nazistiske lærere blev der lagt en dæmper på den nazi- 
stiske agitation. ${ }^{47}$ Aktionsudvalget havde indsamlet materiale om den nazistiske propaganda i Danmark. Propagandaen skete blandt andet via rundskrivelser udsendt til tyske statsborgere med opfordring til indmeldelse i nazistpartiet og $i$ forbundet Venner af Hitlerbevægelsen«. Sagerne og bevismaterialet blev sendt til politiet, der efterforskede de pågældende situationer. ${ }^{48}$

\section{Sammenfatning}

Der er flere elementer af væsentlig betydning, når man kort skal opsummere, hvorfor og hvordan de tysksindede arbejdere tog afstand til nazismen og den nazistiske indflydelse i Danmark.

De forskellige identitets- og loyalitetsforhold har haft væsentlig betydning i forbindelse med afstandstagen og bekæmpelse af nazismen i Danmark. Efter 1920, hvor det tyske Socialdemokrati i Sønderborg blev en del af det danske Socialdemokrati, blev de tysksindede stærkere knyttet til Danmark - især politisk. I forhold til det tyske mindretals tilknytning til Danmark var der store forskelle både politisk og identitetsmæssigt. Da nazismen vandt i Tyskland, og det tyske mindretal i Danmark fik et tydeligt nationalt præg, var det ikke fjernt for arbejderbevægelsen at offentliggøre en klar afstandtagen fra denne ideologi. Grundet den stærkere tilknytning til Danmark blev det derfor mere naturligt for de tysksindede arbejdere at modsætte sig påvirkningen fra det nazistiske Tyskland, end det var for det tyske mindretal repræsenteret ved SW.

Ydermere har muligheden for afstandstagen også et økonomisk aspekt. Den økonomiske uafhængighed af Tyskland gjorde det muligt for socialdemokraterne at bekæmpe nazismen, hvilket var vanskeligere for det tyske mindretal på grund af dettes økonomiske afhængighed af Tyskland.

Man søgte at styrke sammenholdet i Danmark blandt andet gennem store idrætsstævner. Aviserne fra sommeren 1933 skrev om, hvordan idrætsstævnerne symboliserede danskheden $i$ landsdelen, og hvordan befolkningen anså disse unge og deres initiativer som værende et værn af grænsen gennem sammenhold. Ved offentligt at udtrykke danskheden blev der gjort opmærksom på befolkningens frygt for nazismen, men stævnerne var også et udtryk for styrke gennem fællesskabet og ønsket om at bevare danskheden.

At de tysksindede arbejdere støttede op omkring disse tiltag, vid- 
ner om støtten til den danske nationalitet på trods af den kulturelle og personlige konflikt, disse mennesker må have været i. Man ønskede danskheden i landsdelen, man onskede fred og fordragelighed, og man ønskede at ytre sig imod nazismen, selvom man havde en tysk baggrund.

Inden for partiets rammer var man bevidst om den tysksindede del af medlemmerne, og partiets kerne støttede op om dette ved blandt andet at afholde tyske arrangementer. Man søgte at udtrykke forståelse for og accept af medlemmernes historie og tyske kultur. Dette viser en gensidig respekt og forståelse for den identitets- og tilhørskonflikt, de tysksindede medlemmer befandt sig i. Forståelsen gik begge veje: Både fra de tysksindede, der valgte danskheden grundet det politiske sammenfald, og fra de dansksindede, der ønskede et sammenhold med de tysksindede medlemmer i partiet og med respekt for deres tyske baggrund.

I Tyskland blev både socialdemokraterne og kommunisterne forfulgt af nazisterne allerede i de første måneder efter Hitlers magtovertagelse. Ud over at de tysksindede arbejdere i Danmark havde venner og familie i Tyskland, der berettede om nazisternes voldelige overfald, havde de også partifæller, der var ofre for den nazistiske ideologi. De tysksindede arbejdere i Sønderborg var en del af den gruppe, der passivt demonstrerede mod nazismen gennem idrætsstævner. De tog gennem Tinglev-resolutionen afstand fra nazismen generelt både på dansk og tysk jord.

\section{KILDER}

Utrykte kilder

Lokalhistorisk Arkiv for Arbejderbevægelsen i Senderborg Kommune:Socialdemokratisk forening, generalforsamling 29.3.1933, protokol, A 4040.

Socialdemokratisk forening, generalforsamling 20.4.1933, protokol, A 4040.

Socialdemokratisk forening, partimøde 31.7.1933, protokol, A 40-40.

Socialdemokratisk forening, medlemsmode 6.5.1935, protokol, A 40-40.

Socialdemokratisk forening, bestyrelsesmøde 19.8.1933, protokol, A 40-40.
Trukte kilder

Dybbel Posten

Det tysk-nationalsocialistiske fremstød i Nordslesvig, 5.4.1933.

De tyske grænseflyttere, 11.4.1933.

Nazister og socialister, 18.4.1933.

I.P Nielsens Tinglev-tale, 19.4.1933.

12.000-15.000 Mennesker til stævne i Tønder, 13.5.1933.

\section{Sonderborg Social-Demokrat}

$\mathrm{Da}$ Hitler endelige nåede magtens tinde, 31.3.1933.

Tyskland i blodets tegn, 3.2.1933.

Socialdemokratisk blad forbydes, 4.2. 1933. 
Flere dræbte, nazi frikendes, 6.2.1933.

Nazistbølgen og de tyske arbejdere, 25.3.1933.

Mod splittelse, fascisme og diktatur, 29.3.1933.

Farvel til det tyske naziblad, 30.3.1933.

Den sønderjyske situation, 10.4.1933.

Kampfront mod nazi, 18.4.1933.

Fra national til nazistisk, 25.4.1933.

15.000 til ungdomsstæevne i Tønder, 13.5.1933.

Forbudet og Tinglevresolutionen, 22.5. 1933.

Dybbølstævne i sol og sommer, 12.6 . 1933.

Den tyske ærlighed er ødelagt af de nazistiske magthavere, 28.7.1933.

„Parlamentarismen er død «, 30.9.1933.

Pastor Schmidt på uærlige veje, 25.9.1933.

\section{LITTERATUR}

Andersen, Morten, 2008. Den folte grænse. Slesvigs deling og genopbygning 1918-1933. Aabenraa, Historisk Samfund for Sønderjylland.

Becker-Christensen, Henrik, 1995: Grænsen i 75 år. 1920-1995. Aabenraa, Institut for Grænseregionsforskning.

Bohn, Robert m.fl., red., 2001: Nationale mindretal $i$ det dansk-tyske grænseland 1933-1945. Aabenraa, Institut for Grænseregionsforskning.

Fink, Troels, 1955: Sonderiylland siden genforeningen i 1920 . København, J.H. Schultz Forlag.

Hansen, Hans Schultz m.fl., red., 2009: Sønderjyllands Historie 2. Efter 1815. Aabenraa, Historisk Samfund for Sonderjylland.

Klatt, Martin, 2006: Fra modspil til medspil? Granseoverskridende samarbejde $i$ Sanderjylland/Schleswig 1945-2005.
Hejmdal

En kraftig arbejderresolution mod naziagitationen, 18.4.1933.

Sønderjydsk ungdom er nordens grænsevagt!, 13.5.1933.

Nazi-agitationen i Nordslesvig, 17.5. 1933.

Nu skal der arbejdes aktivt for den tyske nazisme i Nordslesvig, 6.6.1933.

Dybbøl stævnet: En storslået dansk tilkendegivelse, 12.6.1933.

Det tyske socialdemokrati forbudt!, 26.6.1933.

Jydske Tidende

Et socialdemokratisk krav, 30.4.1933.

"Gleichschaltung « i nazi-hvervningen i Nordslesvig, 17.5.1933.

Aabenraa, Institut for Grænseregionsforskning.

Kristensen, Henrik Skov m.fl., 2003: Sonderiylland under krig og besættelse 1940-1945. Aabenraa, Historisk Samfund for Sonderjylland.

Noack, Johan Peter, 1974: Det tyske mindretal $i$ Nordslesvig under besættelsen. Århus, Dansk Udenrigspolitisk Institut.

Salomon, Kim, 1980: Konflikt i grænseland. Sociale og nationale modsæetninger $i$ Sonderiylland 1920-33. Kobenhavn, Gyldendal.

Sonne, Harding, 1974: Stauning eller kaos. Socialdemokratiet og krisen i trediverne. Kobenhavn, Hans Reitzels Forlag.

Sørensen, Frode, 2008: Revolutionen og Magten. Sonderborg-arbejdernes historie 1872-1922. Haderslev, Museum Sønderjylland - Senderborg Slot.

\section{NOTER}

1. www.gravsted.dk/ person.php?navn $=$ troelsfink

2. Kristensen m.fl. red. (2003), s. 76.

3. Salomon, s. 55 .
4. Sørensen, s. 32.

5. Fink, s. 87.

6. Jensen, Bernard Eric, 2006: "Arbejderbevægelse", Gads Historie Leksikon. København, Gads Forlag. 
7. Sørensen, s. 14.

8. Hansen m.fl., red., 2009, s. 264.

9. Sørensen, 2008 , s. 151.

10. Hansen, 2009, s. 268.

11. Hansen, 2009, s. 269.

12. Salmomon, 1980, s. 47. Det kan oversættes til: »Enhver stemme er et højtideligt lofte om trofastheden til det tyske folk."

13. Salomon, 1980, s. 49-50.

14. Salomon, 1980 , s. 50 .

15. Salomon, 1980, s. 54.

16. Salomon, 1980, s. 53.

17. Salomon, 1980 , s. 50 .

18. Sorensen, 2008, s. 169.

19. Protokol, generalforsamling, 29.3. 1933.

20. Sørensen, 2008 , s. 160.

21. Sørensen, 2008, s. 157.

22. Protokol, partimøde, 31.7.1933.

23. Protokol, bestyrelsesmøde, 19.8. 1935.

24. Sørensen, 2008, s. 170.

25. Protokol, generalforsamling, 8.7.1935.

26. Sonderborg Social-Demokrat, 28.7.1933.
27. Sonderborg Social-Demokrat, 30.9.1933.

28. Senderborg Social-Demokrat, 25.9.1933.

29. Sørensen, 2008, s. 171.

30. Srrensen, 2008, s. 154.

31. Sørensen, 2008 , s. 153.

32. Hansen, 2009, s. 247.

33. Hansen, 2009, s. 249.

34. Sonderborg Social-Demokrat, 31.1.1933.

35. Senderborg Social-Demokrat, 4.-6.2.1933.

36. Dybbøl-Posten, 11.4.1933

37. Sonderborg Social-Demokrat, 21.3.1933.

38. Hejmdal, 18.4.1933.

39. Protokol, ekstraordinær generalforsamling, 20.4.1933, Lokalhistorisk Arkiv for Arbejderbevægelsen i Sonderborg Kommune.

40. Hansen 2009, s. 329.

41. Hejmdal, 13.5.1933.

42. Hejmdal, 12.6.1933.

43. Sonderborg Social-Demokrat, 26.6.1933.

44. Protokol, partimede, 31.7.1933.

45. Protokol, generalforsamling 8.7.1935.

46. Protokol, partimøde, 31.7.1933.

47. Protokol, partimede, 31.7.1933.

48. Hejmdal, 17.5.1933.

\section{Zusammenfassung}

Die Arbeiterbewegung in Sonderburg wurde von deutsch gesinnten Arbeitern, die aus Deutschland kamen, gegründet. Durch die neue deutsch-dänische Grenze von 1920 entstand in Nordschleswig eine deutsche Minderheit, aber deutsche und dänische Arbeiter sammelten sich in der dänischen sozialdemokratischen Partei. Die deutsch gesinnten Mitglieder gaben zum Ausdruck, dass die politische Ideologie wichtiger sei als die nationale und kulturelle Zugehörigkeit.

Nach der Machtübernahme Hitlers im Januar 1933 nahmen die Sozialdemokraten von der Nazifizierung der deutschen Minderheit in Dänemark Abstand und versuchten den Nationalsozialismus auf deutschem und dänischem Boden zu bekämpfen. Zur offiziellen Abstandsnahme kam es beim Tinglev-Treffen im April 1933, wo man sich auf eine Resolution einigte.

Es gab bei den deutsch gesinnten Arbeitern mehrere Gründe für die Abstandsnahme vom Nationalsozialismus. In Deutschland wurden die Arbeiterparteien verboten und ihre Mitglieder verfolgt. Die deutsch gesinnten Mitglieder in Dänemark hörten durch Freunde und Familie von den Erlebnissen mit dem Nationalsozialismus. 